\title{
Problems of the Real Estate Cadastre against the Background of Economic, Political, Legal and Technological Transformations
}

\section{Introduction}

The real estate cadastre is one of the official systems recording information about the real state of terrain, without which proper land administration and management would not be possible. Cadastral data are the basis for planning the directions of spatial development, issuance of administrative decisions and infrastructure management [3].

The current, dynamic development of the Polish cadastral system is owed, among others, to advanced information technologies, which enable the recording, storage, processing and sharing of very large quantities of data on land, buildings, premises as well as the owners or holders of these objects in the system. Another equally important factor causing actions aimed at modernization of the real estate cadastre is the growing demand for information on space, already not only 2D, but also 3D or 4D. It is expected that the cadastral system will become an instrument supporting registration, analytical and implementation actions, among others in the management of infrastructure objects, which include, e.g. bridges, tunnels, the underground, underground car parks, etc.

3D geovisualization is one of many important challenges posed to cadastral systems in recent years. Due to innovative GIS tools, there is a real chance that the traditional 2D cadastre with its development potential and possibilities will become the cadastre of the latest generation, enabling, among others, 3D visualization of objects, including their situation under or above the ground surface.

This study discusses the problems of the real estate cadastre against the background of economic, political, legal transformations as well as presents the concept for the database architecture of a multi-dimensional cadastral system

* University of Warmia and Mazury, Department of Cadastre and Spatial Management, Olsztyn, Poland 
supporting the management of infrastructure objects with an indication of source materials necessary for its development.

\section{Real Estate Cadastre against the Background of Economic, Political and Legal Transformations}

The real estate cadastre is a uniform collection for the whole country of systematized, updated data on land, buildings and premises, their owners and other natural persons and corporate bodies holding these lands, buildings and premises [8]. Because of its practical importance, it is continually updated to more fully and efficiently supply to state institutions and physical persons information with a broad scope and availability on land, the degree and forms of its development and its natural resources and utility infrastructure. This is reflected in cadastre development stages - from the land cadastre to the multi-purpose cadastre.

The first cadastral systems introduced were closely linked with the tax system of the state. They were established as a result of the demand for standardization of taxes. Determination of the owners of real estate properties and the recording of the rights as well as encumbrances and servitudes established on real estate properties was the aim of the introduction of the legal order in real estate. Geodetic surveys contributed to the unambiguous location of real estate properties and learning their characteristics, designation and manner of use.

The laws which regulated the establishment and modernization of the Land and Property Register in Poland and the manner of formation of this system can be divided into three stages:

1) An attempt to establish the Land and Property Register:

- decree on the land and building cadastre of 24 September 1947,

- regulation of 6 December 1950 on the procedure for the organization, establishment and maintenance of the real estate cadastre.

2) Establishment of the Land and Property Register:

- a simplified Land Register (created in 1949),

- order on Determination of Uniform Data on the Area of Agricultural Land and Other Land and Uniform Nomenclature for Individual Types of Land of 17 July 1951,

- decree on the Land and Property Register of 2 February 1955: stage 1 (ca 1 year) - obtaining the most reliable data on land on the basis of available materials, stage 2 - comparison with reality, preparation of base maps, ascertainment of the actual state of land holding,

- order of the Ministers of Agriculture and Municipal Services of 20 February 1969 on the Land Register. 
3) Modernization of the Land and Property Register:

- Geodetic and Cartographic Law of 17 May 1989,

- regulation of the Ministers of Spatial Development and Construction, and Agriculture and Food Economy of 17 December 1996 on the Land and Property Register,

- regulation of the Minister of Regional Development and Construction of 29 March 2001 on the Land and Property Register,

- project of the Minister of Administration and Digitization of 2012 amending regulation of 29 March 2001 on the Land and Property Register.

The formation of the real estate cadastre is also influenced, besides the abovementioned laws, by the political transformations which occurred in Poland after 1989 and restored the due importance to the right of property. This led to the introduction of a constitutionally guaranteed protection of property rights as a fundamental feature of the state's political and government system in 1997. The transition from a centrally-planned to a free market economy resulted in a number of changes in the social, economic and political situation of our state. The free market economy requires that all decisions, both administrative and economic, take into account the basic factors of value and property rights - the elements which are the contents of a modern real estate cadastre.

The contemporary cadastre is a system called multi-purpose or multi-functional. This results from the nature of cadastral data, their universality and the possibility of their use in different areas of economic and social life to meet the needs of a growing group of users. The statutory provision that the register data are the basis for spatial planning, land management, guaranteeing property rights and security of possession, calculation of taxes, real estate market monitoring and statistical data generation indicates that the real estate cadastre has been a multi-purpose instrument since the very beginning of its existence. The cadastre, as a separate, autonomous system, provides individual and group users with original information on, among others: the location, boundaries, manner of use, value, technical data and legal relationships with specific entities.

The second aspect of the use of cadastral data consists in the application of appropriate GIS tools and performing different types of spatial analyses on the basis of cadastral information, the generation of graphic descriptions and the preparation of statistical summaries. Another aspect of the use of cadastral data consists in their integration with information from other systems, particularly from the Land and Mortgage Register system. For this purpose, a new definition was introduced for the registration unit, as the equivalent of a real estate property (within a district). Recording was started of information about the land, building and premises real estate entered in the register of land, buildings and premises, respectively, as well as information about buildings and premises constituting component parts of real estate properties, as presented in the files of buildings and premises. 
The changing technical, legal and administrative conditions forced cadastre reforms consisting, among others, in:

- replacement of traditional cadastral maps with numerical maps,

- cadastre automation,

- introduction of new objects (building, premises),

- extension of databases with new attributes,

- connection of the cadastre with other information systems and public registers,

- introduction of standards for data exchange between systems.

Adaptation of the cadastre to new conditions for economic and time reasons takes place by modernization of existing sets of cadastral data.

The real estate cadastre is currently faced with new challenges, resulting from the provisions of the EU Directive on spatial information systems and the Act on Spatial Information Infrastructure issued on 4 March 2010 (Polish Journal of Laws No. 76, item 489), which is the implementation of the INSPIRE Directive for Polish conditions. These regulations resulted in a number of changes in the Geodetic and Cartographic Law, the basic legal act for maintenance of the real estate cadastre. The provisions of the above-mentioned laws indicate that since the Land and Property Register is among the basic public registers creating the information infrastructure of the state, it is therefore necessary to accelerate the modernization actions for this system and adapt it to the principles of inter-operability.

The real estate cadastre can be called a dynamic system, providing information on the expanding needs of the market, as it records the three basic elements which are the basis for proper land administration and management: the manner of use, ownership and value of real estate. A real estate property can be considered physically and legally. A land real estate property is identified in the real estate cadastre by the numerical description of its boundaries, using $x, y$ coordinates (physical element). The horizontal boundaries delimit the real estate property as an area to which specific rights are assigned (legal element) in a planar $x$, y system.

A land real estate property is a three-dimensional structure, so it has its horizontal and vertical boundaries. The question to be answered is whether a land real estate property, as a thing, is a two-dimensional plane and the right of property extends to the space "above" and "under" this plane or a land real estate property, as a thing, is a solid and the scope of the right of property is determined by the boundaries of this solid [6]. The use and development of the space "above" and "under" land results from the need for more intensive development of space, mainly urbanized or carried out linear investment projects and infrastructure objects constructed "above" land, e.g. bridges or overpasses. This is reflected in the cadastral problems and the creation of the 3D cadastre. 


\section{Concept for the Database Architecture of a Multi-Dimensional Cadastral System}

Rapid changes occurring in the surrounding space determine the need for efficient management of terrain data. It is difficult to manage space resources effectively and efficiently without an efficient GIS-class information system [2]. The contemporary definition of the real estate cadastre should therefore be closer to the concept of GIS systems and take into account issues related to the modelling of data, including the spatial data of recorded registration objects as well as the rights associated with them [1].

3D geovisualization is one of the trends of GIS development which enables effective and impressive analysis and representation of the surrounding space [9]. Record parcels, buildings and other cadastral objects, as well as the rights associated with them, are currently presented using 2D vectors (points with known $x$ and $y$ coordinates). According to Art. 143 of the Civil Code, the land property rights extend to the space above and under its surface. However, it is not known how high above the land surface or how deep under its surface the property rights extend.

The importance of the traditional real estate cadastre as an institution ensuring proper land administration and management is enormous and unquestionable. However, interest in 3D cadastral information is growing steadily, especially in areas of intensively developing construction. It is important and needed in situations of the so-called "multi-level real estate property use", this mainly refers to building objects constructed under the surface of a real estate property (e.g. tunnels, underground car parks) and above its surface (e.g. bridges).

It is therefore appropriate to require that the modern real estate cadastre supported by GIS technology is able to record the objects of the system not only in 2D, but also in 3D (points with known $x, y, z$ coordinates), defining how high above and how deep under the land surface the right of property reaches.

The spatial real estate cadastre will be understood in this study as a GIS database in the form of:

- graphical databases - numerical maps (2D or 3D),

- descriptive databases - descriptive attributes of 2D or 3D graphic objects.

The development of a concept for the database architecture, which is the key component of a multi-dimensional cadastral system, was preceded by the determination of its two main potential functions, i.e. the registration function and the analytical function. It should be added that the concept for the architecture of a multi-dimensional cadastral system in this study is a development of previous 2D solutions. Therefore, potential registration operations of a multi-dimensional database are the registration of legal status at different levels of real estate properties (on land and above and under its surface). Potential analytical functions include 3D spatial analyses of cadastral objects (among others, 3D modelling of buildings). 
The value of each database is determined, among others, by its application for the accomplishment of different aims and the quality of the data it offers and not the IT tools used for its construction. Therefore, developing the concept of a multidimensional cadastral database, each user should be provided, among others, with:

- a location on a numerical map of 2D and 3D objects with determined legal status with attributes,

- adaptation of the descriptive base to the contents of the geometrical base,

- the possibility of combining data originating from different sources,

- protection of legal data while ensuring continuous updating of information about the spatial layout.

Figure 1 presents the schematic diagram of a multi-dimensional cadastral database which takes into account the scope of data and the sources of their acquisition important in the creation of the multi-dimensional cadastre, the structure of data layers and an analysis and reporting of the entered data.

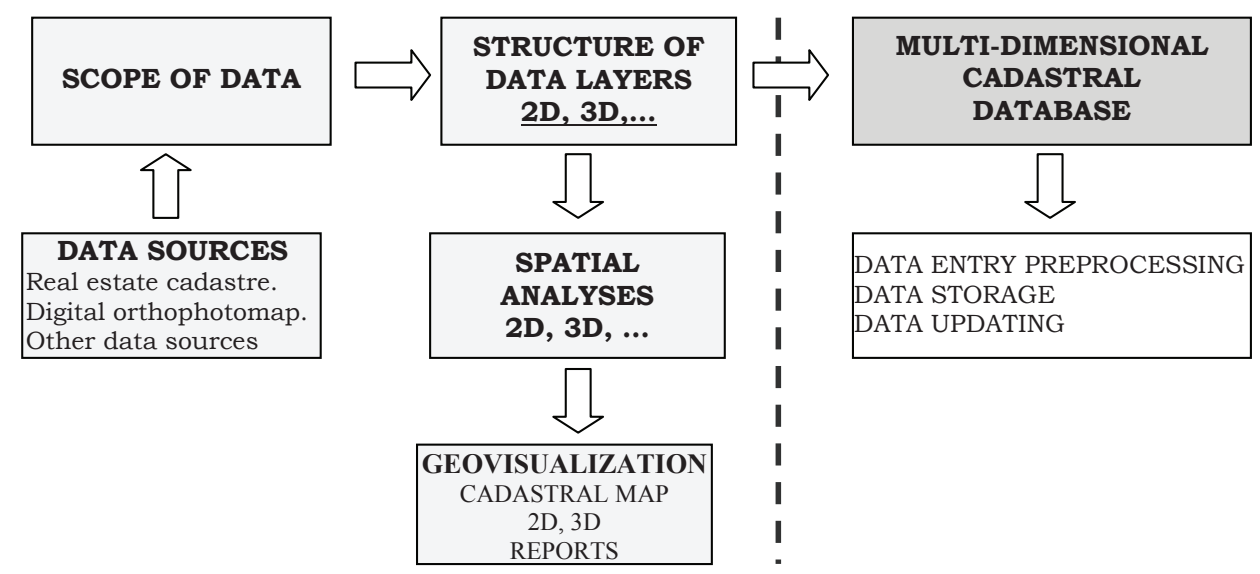

Fig. 1. Schematic diagram of a multi-dimensional cadastral database

The traditional two-dimensional real estate cadastre is one of the main data sources feeding the designed base, which results from the earlier assumption to maintain the existing cadastral system, but with the possibility of, among others, 3D modelling of its objects.

There is a whole range of potential sources of 3D information about buildings, which enables the visualization of the body of the building depending on its level of detail - LOD. One of them is the real estate cadastre, which provides data on the two-dimensional ground floor of buildings and the number of their floors. It is the simplest and cheapest method of 3D geovisualization for housing estates - areas built up with multi-storey residential buildings (simple block models with flat roofs). The data for the preparation of a three-dimensional building development 
model can also be acquired on the basis of laser scanning, stereoscopic aerial and satellite photographs and from LIDAR laser surface measurements [7]. If remote sensing methods are used, the level of detail for 3D buildings includes not only simple block models, but also the shape of roof coverings and the structure of building facades.

Spatial analyses are the main aim of the construction of GIS systems because they enable the transformation of source data into information about the surrounding space. This information can become the basis for decision support [3].

The interpretations of the prepared spatial and attribute data collection, supporting the management of infrastructure objects, can be made both a priori and a posteriori. This predisposes the users of multi-dimensional cadastral databases to the preparation of a number of multi-criteria comparative analyses - taking into account the full spectrum of input data, both "before" and "after" the selection of the optimal solution [4]. This means the possibility of tracing and interpretation of positive or negative effects of taken decisions as well as the creation of prognostic scenarios concerning, among others, changes in the legal status of real estate properties, planned investment projects, transformations of the spatial structure of the terrain, urban planning analyses or crisis management.

The results of spatial analyses are influenced, above all, by the quality of collected data, i.e. their completeness, logical coherence and validity [5]. Spatial analyses are performed on the basis of a layered data structure (Fig. 2).

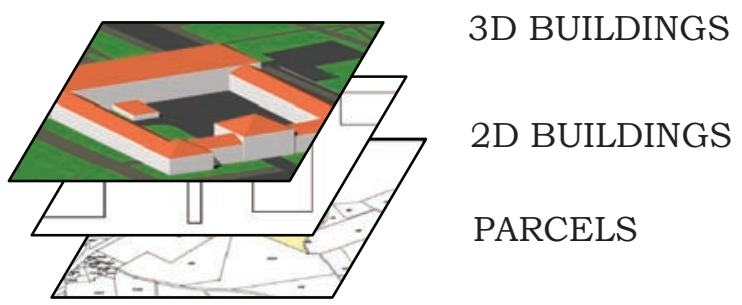

Fig. 2. Layered data structure

Spatial analyses performable on data sets collected in a multi-dimensional cadastral database are based on analytical algorithms - operations examining the relationships between objects and phenomena concerning different elementary surfaces located on different geometrical information layers. These include, among others, a combination of the contents of two or more data layers and the search for and classification of geometrical objects meeting the set logical condition and combination of attributes (data from two tables) in one attribute table, with the assumption that these attributes concern the same places (share the same location in space) [4].

The characteristic feature of GIS systems, as distinct from other systems, is the possibility of spatial data visualization in the form of a map. Although many 
spatial analyses and many GIS functions can be performed without a map display, the availability of this function nevertheless has a fundamental character in every spatial information system [3]. A multi-dimensional cadastral map will not only be a simple visualization of the selected area. Its task will be to discover spatial knowledge essential in the management of infrastructure objects, especially in intensively developing areas. However, it must be borne in mind that, according to the current laws, the boundaries of real estate properties are two-dimensional. Therefore, for a multi-dimensional cadastral map to be able to fulfil its role, it is necessary to start by an amendment of laws introducing a number of regulations enabling the use of the space above or under the surface of a real estate property while ensuring the exercise of rights on its surface.

\section{Summary}

The directions of changes and the development of the real estate cadastre result mainly from society's needs to solve new emerging problems related to, among others, globalization, sustainable development, crisis management and the development of spatial information technologies. The real estate cadastre, because of its information value used in the broadening process of natural resources management, is being continually modernized. Efficient real estate management currently depends on the degree of the cadastre's modernity.

In determining the course of real estate boundaries in a two-dimensional system, it is often forgotten that a land real estate property is a spatial formation whose right of property is also above and under the surface. Delimitation of the boundaries in the first case, after the application of appropriate survey techniques is not a serious problem, while the delimitation of spatial boundaries is not so unambiguous. The problem connected with the delimitation of these boundaries appears when it is necessary to determine the rights to minerals or groundwaters the owner of a given real estate property is entitled to. This is reflected in the problems of a multidimensional cadastre.

Dynamically developing economic relations between entities, both private and public, as well as the progressive development of infrastructure give rise to the need for the development of new legal solutions to meet the needs arising from the complexity of these relations. The rapidly-increasing building density in cities and the consequent shortage of profitable surfaces for construction causes investors to raise the need for the development of a legal framework for the implementation of investment projects above or under the surface of real estate properties if the implementer of the investment project is not the owner or perpetual lessee of one or more real estate properties, occupied for this investment project [10]. Therefore, for the traditional real estate cadastre to become a modern multi-dimensional system, legal changes are, above all, necessary on multi-level real estate property use and support 
in the form of mutual exchange of experience, information flow and assistance from those EU countries (e.g. Sweden) which have already developed legal and technical solutions enabling the optimal use of the space above and under its surface as well as on its surface.

\section{References}

[1] Felcenloben D.: Kataster nieruchomości. Gall, Katowice 2009.

[2] Głuszek K.: Korzyści wynikające z funkcjonowania SIP w jednostce samorządu terytorialnego. Konferencja „Rozwój usług i aplikacji informacyjnych dla ludności na terenie województwa kujawsko-pomorskiego", Ciechocinek 2009 [typescript].

[3] Gotlib D., Iwaniak A., Olszewski R.: GIS. Obszary zastosowań. Wydawnictwo Naukowe PWN, Warszawa 2008.

[4] Konieczna J., Trystuła A.: Przykłady analiz przestrzennych $w$ badaniach warunków glebowych obszarów wiejskich na potrzeby systemu GIS. Ekonomia i Środowisko, nr 1 (39), 2011, pp. 183-194.

[5] Konieczna J., Trystuła A.: Kataster nieruchomości jako podstawa SIP wspomagajacego gospodarowanie nieruchomościami. Studia i Materiały Towarzystwa Naukowego Nieruchomości, vol. 19, no. 4, 2011, pp. 33-44.

[6] Matusiak G.: Instytucje prawne pozwalajace na korzystanie z przestrzeni nad powierzchnia gruntu. XX Krajowa Konferencja Rzeczoznawców Majątkowych "Gospodarowanie przestrzenią »nad « i »pod « gruntem", Katowice 28-30 września 2011, Śląskie Stowarzyszenie Rzeczoznawców Majątkowych, Katowice 2011, pp. 57-75.

[7] Medyńska-Gulij B.: Kartografia i geowizualizacja. Wydawnictwo Naukowe PWN, Warszawa 2009.

[8] Ustawa z dnia 17 maja 1989 r. - Prawo geodezyjne i kartograficzne. Dz. U. nr 30, poz. 163 [The Act of 17 May 1989 - The Geodetic and Cartographic Law, Journal of Laws No. 30, item 163].

[9] 24GIS, [on-line:] www.24gis.pl [access: May 21, 2011].

[10] Założenia do projektu ustawy o odrębnej własności obiektów budowlanych. Projekt $z$ dnia 14 lipca $2010 r$. [Guidelines of the bill on separate ownership of building objects of 14 July 2010]. [on-line:] http://grafik.rp.pl/grafika2/572846 [access: November 30, 2013]. 